\title{
Türkiye'deki Elektronik Ticaret Uygulamalarına Müşteri Gözünden Bakış ve İyileştirme Önerileri*
}

\author{
Engin YILMAZ**, İbrahim Sarper KARAKADILAR ${ }^{* * *}$
}

Öz

Günümüzde e-ticaret uygulamaları küresel çapta etkileyici bir şekilde büyüyerek nihai tüketicilerin sıklıkla tercih ettikleri bir alışveriş ortamı haline gelmiştir. Gelişmiş ve gelişmekte olan ülkelerin firmadan-müșteriye (B2C) doğru perakende e-ticaret işlem hacimlerinin yüksek olmasına rağmen, Türkiye'de ise benzer bir performans ortaya konulamadığı görülmektedir. Bundan dolayı bu çalışmanın amacı Türkiye'deki e-ticaret pazar potansiyelinin beklendiği düzeyde gerçekleşmemiş olmasının nedenlerini tespit ederek çözüm önerileri geliştirmektir. Bu doğrultuda, öncelikle sektör bazında yapılmış araştırmalar incelenmiş ve bu çalışmalardan faydalanılarak bir anket formu geliştirilmiştir. Daha sonra bu anket formu İstanbul'da e-ticaret müşterisi olarak tanımlanan, orta gelir düzeyinde maaşlı çalışan 312 kişiden oluşan örneklem kitlesine uygulanmıştır. Toplanan anketler neticesinde, örnek kitlenin e-ticaret uygulamaları için harcadığı alışveriş bütçesi ile bu işlemler için ayırdığı zamanın çok düşük düzeyde olduğu görülmektedir. Buna karşın anket katılımcılarının e-ticaret firmalarının performansını değerlendirilirken önem verdikleri unsurlar olarak satış sonrası hizmet kalitesi ve teslimat süresinin makul olması belirlenmiştir. E-ticaret uygulamalarıyla ilgili genel olarak müşterilerin en büyük çekincesiyse güvenlik algısı sorunudur. Bu sorunun üstesinden gelinmesi mikro ölçekte firma bazında değil ancak makro boyutta devlet ve sektörün hep birlikte hareket etmesiyle ele alınmalıdır. Bu doğrultuda Türkiye yerli milli siber güvenlik tedbirlerini geliştirmeli ve sektörde faaliyet gösteren firmalara yönelik yasal düzenlemeler oluşturmalıdır.

\section{Özgün Araştırma Makalesi (Original Research Article) \\ Geliş/Received: 21.05 .2018 \\ Kabul/Accepted: 18.12 .2018 \\ DOI: http://dx.doi.org/10.17336/igusbd.424772}

* Bu çalışma, Engin Yılmaz'ın Nişantaşı Üniversitesi, Sosyal Bilimler Enstitüsü'nde Dr. Öğr. Üyesi İbrahim Sarper Karakadılar'ın tez danıșmanlığında gerçekleştirilen “Türkiye'de Faaliyette Olan Elektronik Pazaryerlerinin Nihai Tüketiciler Tarafından Konumlanması Üzerine Ampirik Bir Çalışma" başlıklı yüksek lisans tez çalışmasından türetilmiştir.

** Türk Kızılayı Maltepe Şubesi Kan Departmanı, İstanbul, Türkiye, E-posta: enginyilmaz@kizilay.org.tr ORCID ID http://orcid.org/0000-0002-8247-8811

${ }^{* * *}$ Dr. Öğr. Üyesi, Kahramanmaraş Sütçü İmam Üniversitesi, Türkoğlu Meslek Yüksekokulu, Kahramanmaraş, Türkiye, E-posta: iskarakadilar@ksu.edu.tr, ORCID ID http://orcid.org/0000$\underline{0002-1785-5756}$ 
Engin Yılmaz, İbrahim Sarper Karakadılar, "Türkiye'deki Elektronik Ticaret Uygulamalarına Müşteri Gözünden Bakış ve İyileştirme Önerileri”, İstanbul Gelişim Üniversitesi Sosyal Bilimler Dergisi, 6 (1), Nisan 2019, ss. 53-75

Anahtar Kelimeler: Firmadan Tüketiciye (B2C), E-ticaret, E-Perakendecilikte Kalite Ölçeği, Müşteri Güven Algısı, Müşteri Tercihi

\title{
Customers' Approach and Improvement Suggestions for Electronic Commerce Applications in Turkey
}

\begin{abstract}
Nowadays in globally e-commerce applications have grown dramatically and it has become the commonly preferred shopping medium by the end customers. Despite the fact that the high volume of $\mathrm{B} 2 \mathrm{C}$ retailing e-commerce rate in developed and emerging countries, Turkey does not show that performance. Therefore, the aim of this study is to develop the suggestions and identify the reasons for the unrealized market potential of Turkish e-commerce sector. In that context, some sector related market studies have been investigated and then based on these studies' results a structured questionnaire form has been generated. Later, this survey has been conducted to sampling which includes 312 respondents, who are identified as potential e-commerce customers in Istanbul. The collected data show that people, who included sampling, are not into spending their shopping budget and their spare time for e-commerce implementations. According to the results, the operational performance of e-commerce firms was determined by respondents as "post-sales service quality" and "appropriate lead-time". The crucial problem for the Turkish customers about e-commerce applications is the security issue. To overcome this issue the solving efforts should be handled on the macro level, instead of individual strives of each e-commerce companies at the micro level. For that purpose, Turkey should develop its own national cybersecurity protection and also should regulate the Turkish e-commerce sector structure based on the firm's competencies.
\end{abstract}

Keywords: Business to Consumer (B2C), E-commerce, E-Tail Quality Scale, Customers' Trust Perception, Customers' Behavior Preferences

\section{Giriş}

1990’lı yılların ortasından itibaren dünya genelinde internet bağlantısı hızla yayılmaya başlamış ve artık ev halkının gündelik yaşamında bireysel amaçlı internet kullanımı hayatın vazgeçilmez bir parçası haline gelmiştir. Bu da zamanla beraberinde insanların alışveriş işlemlerini çevrimiçi bağlantı yoluyla sanal ortama kaydırmasına neden olmuş ve e-ticaret kavramı ortaya çıkmıștır. En genel ifadesiyle e-ticaret; "sipariș alıp vermek için tasarlanmış elektronik ortamlarda, bilgisayar ağları üzerinden yürütülen mal/hizmet alışverişi”" şeklinde tanımlanabilir. E-ticaret işleminin taraflarına bakıldığındaysa "ticari işletmeler, hane halkı, özel ya da kamu kurumları" şeklinde geniş bir yelpazede her türlü bireysel veya kurumsal internet kullanıcılarından oluşmakta olduğu görülmektedir. Alışveriş işleminin mübadele kısmıysa (ürün/hizmet teslimi ile 
Engin Yılmaz, İbrahim Sarper Karakadılar, “Türkiye'deki Elektronik Ticaret Uygulamalarına Müşteri Gözünden Bakış ve İyileştirme Önerileri”, İstanbul Gelişim Üniversitesi Sosyal Bilimler Dergisi,

6 (1), Nisan 2019, ss. 53-75

ödeme işleminin yapılması) sanal ortamda çevrimiçi veya gerçek ortamda fiziksel olarak yapılmaktadır (TÜBISAD, 2014, s.2).

İnternet kullanımının yaygınlığı açısından, dünyada e-ticaret ekonomisinin etkinliğiyle ilgili verilere bakıldığında; başta İngiltere olmak üzere Amerika Birleşik Devletleri, Almanya, Fransa ve Japonya gibi gelişmiş ülkelerin e-ticaret iş hacimlerinin ülke nüfusuna yayıldığı ve işlem miktarının da oldukça fazla olduğu dikkat çekmektedir. Gelişmekte olan ülkeler kategorisinde ise bașta Çin Halk Cumhuriyeti olmak üzere, Polonya, Brezilya ve Rusya'nın benzer șekilde ama biraz daha düşük oranlı olarak internet kullanımının yaygınlığı ile e-ticaret iş hacmi arasında bir paralellik olduğu görülmektedir (TÜBİSAD, 2014, s.15-16).

$\mathrm{Bu}$ anlamda, Türkiye'nin durumuysa benzer kategorideki diğer gelişmekte olan ülkelerden farklı olarak olumsuz yönde ayrışmaktadır. Özellikle, internet kullanımının yaygınlığı diğer gelişmekte olan ülkelerle aynı düzeyde olmasına karşın e-ticaret işlem hacminin ise oldukça düşük düzeyde seyretmesi ülkenin ekonomik-ticari verimliliği açısından bir engel olarak değerlendirilebilir (TÜBISAD, 2014, s.15-16).

Yukarıda değinilen sektörel iş potansiyeliyle ilgili tespitler göstermektedir ki Türkiye e-ticaret pazarının işlem hacmi büyüklüğü, benzer ülkelerle kıyaslandığında olması gerektiğinden daha düşük seviyelerde seyretmektedir. Bu durum ise Türkiye özelinde bilimsel anlamda incelenmesi gereken bir araştırma konusunu gündeme getirmektedir. Özellikle e-ticaret işlem hacmi yoğunluğunu etkileyen temel faktörlerden; Türkiye'deki internet erişiminin uygunluğu ve e-ticaret pazarında ürün/hizmet arzının yeterli büyüklükte olduğu düşünüldüğünde, geriye irdelenmesi gereken temel sorun olarak Türk halkının e-ticaret işlemlerine karşı tutumunun, yani algı sorununun ele alınması gerekmektedir (TÜSİAD, 2014, s.16-18).

Bu nedenle, bu çalıșma özelinde Türkiye'deki e-ticaret potansiyelinin durum tespitini yapmak, müşteri bakış açısından e-ticaret uygulamalarını değerlendirmek amacıyla bir araştırma tasarlanarak yürütülmesi planlanmaktadır. Böylelikle de Türkiye'deki eğitimli, genç kitlenin e-ticaret kullanımıyla ile ilgili davranış şekillerinden yola çıkarak algılarının yorumlanması ve bu doğrultuda makro çerçevede sektörün iyileştirilmesine yönelik çözüm önerilerinin geliştirilmesi hedeflenmektedir.

\section{ARAŞTIRMA KONUSUNUN LITTERATÜR GEÇMIŞi}

Günümüz iş hayatında internet kullanımı; ticari anlamda müşterilerle iletişime geçilen, mal ve hizmet alım satımının sınırsızca yapıldığı bir yer olma yolunda ilerlemektedir (Çelik ve Akgemici, 1998, s.175). Artık internet sayesinde ticaret hayatında işletmelerin faaliyet alanlarının coğrafi sınırları ortadan kalkmıștır (Sarıhan, 1995, s.302). Bir firma artık kolaylıkla kendi coğrafi sınırlarının dışından tedarikçi bulup gereksinim duyduğu hammadde ve/veya diğer girdi malzemelerini temin edebilmektedir. Bununla birlikte yine coğrafi sınırlarının dışındaki dağıtım kanallarına girebilmekte ve hatta direk olarak uzak noktalardaki nihai müșteriye kendisi ulaşabilmektedir. Bunların yanı sıra elektronik ortamda firmanın sürekli hedef müșteri kitlesinin gözünün önünde olması sayesinde, işletmeler potansiyel müșterilerinin zihninde marka bilinci oluşturabilmektedir. Böylelikle firmalar açısından internet 
Engin Yılmaz, İbrahim Sarper Karakadılar, “Türkiye'deki Elektronik Ticaret Uygulamalarına Müşteri Gözünden Bakış ve İyileştirme Önerileri”, İstanbul Gelișim Üniversitesi Sosyal Bilimler Dergisi,

6 (1), Nisan 2019, ss. 53-75

erişiminin müşterilerle temas aracı olarak kullanılması sayesinde müşteriler; firmanın sunduğu mal/hizmet ile ilgili daha fazla bilgi edinebilmekte, sipariş ve rezervasyon süreçlerinde işlemleri kolaylaştırmakta ve çift yönlü olarak bilgi akışının etkinliğini arttırmaktadır (Hasıloğlu, 1999, s.48).

Dünya genelinde e-ticaret pazar hacmi her geçen gün tahmin edilenin de ötesinde önemli ölçüde gelişmesine karşın yine de halen e-ticaret hacminin toplam ticaret hacminin içerisindeki payı dünya genelinde yüzde on, Türkiye için ise yüzde dört gibi düşük oranlarda seyretmeye devam etmektedir (Dünya Gazetesi, 2017). Bununla birlikte mevcut e-ticaret işlem hacminin büyük bir kısmını ise "işletmeden işletmeye (B2B)" elektronik ticaret oluşturmaktadır. Buna karşın "işletmeden tüketiciye (B2C)" elektronik ticaretin işlem hacminin "işletmeden işletmeye (B2B)" klyasla oldukça geride kaldığı bilinmektedir (Kalaycı, 2008, s.143). İşletmeden işletmeye (B2B) elektronik ticaretin gelişmesinde en önemli faktör iş süreçlerinde yer alan gereksiz aracıların ortadan kaldırılmasıdır. Bu sayede işletmeler tedarikçileriyle direkt temas kurarak tedarik yönetimini daha düşük maliyetle gerçekleştirebilmekte ve iş süreçlerini daha etkili dinamik bir yapıya sokabilmektedir (OECD, 2000, s.193-195).

Bu çalışmanın ana araştırma konusu; Türkiye'deki "işletmeden tüketiciye (B2C)" elektronik ticaret yaklaşımının etkinliğinin arttırılması olduğundan dolayı literatür taramasında da bu kapsam üzerine odaklanılarak perakende e-ticaret konusu ele alınmaktadır.

\section{1. İşletmeden Tüketiciye (B2C) E-ticaretin İşlevsel Etkinliği}

İşletmeden tüketiciye (B2C) e-ticaret; internet ağı ve bilgisayar teknolojilerinin gelişimiyle birlikte ortaya çıkan ve firma ile müşteri arasındaki alışverişi geleneksel yönteme göre oldukça kolaylaştıran bir yeniliktir. İnternet üzerinden yapılan elektronik ticaret yeni bir pazarlama yöntemi olmasına karşın ekonomik faaliyetler ve sosyal çevre bakımından radikal değişikliklere yol açabilecek bir etkiye sahiptir. Elektronik ticaret; finans, iletişim ve perakende sektörlerini etkilemekte ve toplumların gündelik hayatında önemli bir yer edinmektedir (McLoughlin, 2002, s.2).

İşletmeden tüketiciye (B2C) e-ticaret sayesinde, yeni pazar sahalarına yatırım yapmak için kaynakları yetersiz olan firmalar, hedefledikleri pazar noktalarına düşük yatırım maliyetiyle girebilmektedirler. E-ticaret, firmanın operasyonel faaliyetlerine hız kazandırdığından ve insan unsurunu da minimuma indirdiğinden maliyetleri azaltır ve firmanın faaliyetlerinde verimliliği arttırır. Satıcılar ile müşteri arasında çok daha sağlıklı bir iletişim imkânı sağladığından hizmet ve ürün kalitesindeki artışa da yardımcı olur. Sektördeki paydaşlar arasındaki bilgi paylaşımının etkinliğini arttırdığı için iş süreçlerinin ve dolayısıyla genel olarak ekonomideki verimliliğinin artmasına da katkı vermiş olur. Firmaların e-ticaret faaliyetlerinde bulunurlarken oluşturdukları veribankası ile müşteri takip sistemi sayesinde, makul maliyet düzeyinde müşteri merkezli pazarlama anlayışı etkili bir şekilde uygulanabilmektedir (Erbaşlar ve Dokur, 2012). Müşteriye sunulan ürün/hizmetin elektronik ortamda pazarlanmasıyla da firmalar ürünün siparișinden teslimatına kadar geçen sürede en az hata ile hızlı ve tam zamanında ürün teslimi gerçekleștirilebilmektedir (Kotler, 2000). Böylelikle de müșteri 
memnuniyetinin üst düzeye çıkması sağlanmaktadır. Ayrıca e-ticaret uygulamalarının işletmenin stok tutma politikasını etkinleştirmesi sayesinde envanter tutma maliyetlerini düşürebilmesine de imkân vermektedir (Kula ve Tatoğlu, 2002). Neticede, e-ticaret sayesinde firmanın ulaşılabileceği müşteri sayısının önceden öngörülebilmesi olanaksız olmakla birlikte, geleneksel ticari yaklaşıma göre firmaların pazar payını ve operasyonel süreçlerinin verimliliğini artacağı şüphe götürmez bir gerçektir.

Müşteri bakış açısından e-ticaret uygulamalarının etkileri değerlendirildiği zaman yine pek çok dikkat çekici unsur ortaya konulmaktadır. Özellikle elektronik pazarlama sayesinde müşteriler, profesyonel satış elemanları ile yüz yüze gelmediklerinden gerçekten satın alma ihtiyacı olmadığı bir ürün/hizmeti ikna edilerek satın almak durumunda kalmazlar. Aynı zamanda alışveriş işlemi için klasik uygulamaya göre çok daha az zaman ve emek harcayarak (örneğin; sıra bekleme gibi olumsuzluklarla karşılaşmaksızın) kolaylıkla alışveriş işlemini gerçekleştirebilirler (Kotler, 2000). Yani, insanların bir e-ticaret işlemini tamamlamak için evden çıkmasına mağaza dolaşmasına gerek yoktur ve siparişi evine teslim edilmektedir. Diğer bir ifadeyle e-ticaret uygulamaları sayesinde tüketiciler; satın almayı düşündükleri bir ürün/hizmet hakkında diledikleri zaman detaylı bilgiye erişip, derhal sipariş verebilme imkânına sahip olup, çok daha uygun fiyatlardan ürün/hizmeti satın alabilme olanağına sahiptirler. Böylelikle günümüzde e-ticaret uygulamalarının ve internetin sunmuş olduğu sınırsız ürün ve marka seçeneği sayesinde, müşterilerin gerçek anlamda pazarı yönlendiren tek güç konumuna geldiği söylenebilir. Artık müşteriler kendilerine sunulanla yetinmek yerine kendisi için en iyi alternatifi kendi başına bir başkasının yönlendirmesine gerek kalmaksızın arayıp bulabilmektedir (Öztürk, 2014, s.56).

Elektronik pazarlama yaparak nihai müșterilere ulaşmak isteyen bir e-ticaret firmasının dikkat etmesi gereken hususların başında ise tasarlayacağı web-sitesinin müşterilere güven veren, kullanımı kolay, siber saldırılara karşı teknolojik güvenlik donanımıyla kendisini koruyabilir olması gelmektedir. Bununla birlikte e-ticaret firmasının web-sayfası müşterilerin dikkatini çekebilmeli ve firmanın müşterilerine sunduğu e-ticaret iş modelinin hedef müşterileri için gerçekten fayda-değer yaratabilir olması da gereklidir (Korkmaz, 2004, s.15).

\subsection{Türkiye'de İşletmeden Tüketiciye (B2C) E-ticaret Sektörünün Özellikleri}

Türkiye'de e-ticaret sektörü akademik anlamda 2000'li yılların başından itibaren yoğun bir şekilde çalışılan araştırma konularından biri olmuştur (Sarısakal ve Aydın, 2003). Bu tip akademik amaçlı çalışmaların dişında, sektörün kendi potansiyelini değerlendirmek için gerçekleştirdiği araştırmalar da önemli ikincil veri kaynakları olarak dikkat çekmektedir. Bu doğrultuda 2014 yılında Türkiye'de e-ticaret sektörünün yapısı TÜSİAD tarafından yürütülen bir araştırmayla detaylı bir şekilde ortaya konulmuştur. Bu raporda; Türkiye'deki internet kullanıcısının sayısının yüksek olması, internet tabanlı ödeme altyapısının ve lojistik-dağıtımı gibi tamamlayıcı (destek) sektörlerin etkili çalışması sayesinde Türk e-ticaret sektörünün büyük bir pazar potansiyeline sahip olduğuna değinilmektedir (TÜSİAD, 2017, s.3;41). Ancak söz konusu 
Engin Yılmaz, İbrahim Sarper Karakadılar, “Türkiye'deki Elektronik Ticaret Uygulamalarına Müşteri Gözünden Bakış ve İyileştirme Önerileri”, İstanbul Gelișim Üniversitesi Sosyal Bilimler Dergisi, 6 (1), Nisan 2019, ss. 53-75

öngörüye rağmen 2017 senesinde tekrardan yapılmış olan çalışmanın bulguları göstermektedir ki 2013-2016 yılları arasında Türkiye'de perakende e-ticaret hacmi beklenilen patlamayı yapamamış ve bu 4 yıllık periyotta sadece $\% 34$ büyüyerek 7.3 Milyar TL'den 17.5 Milyar TL seviyesine çıkabilmiştir (TÜSİAD, 2017, s.44). Özellikle ülkelerin ekonomilerinde e-ticaretin toplam perakende ticaret içindeki payı bakımından değerlendirildiğinde ise Türkiye'nin "Çin Halk Cumhuriyeti, İngiltere, Amerika Birleşik Devletleri" gibi e-ticaret pazar hacmi yüksek olan ekonomilerin seviyesine gelebilmesi için kat etmesi gereken daha çok mesafe olduğu anlaşılmaktadır (TÜSİAD, 2017, s.44).

Türk ekonomisinde e-ticaret pazarının gelişimine bakıldığındaysa 2008 yılının önemli bir milat olduğu görülmektedir. Bu yıldan itibaren özellikle moda-tekstil (giyim), elektronik eşya, mobilya-dekorasyon (ev eşyası), gıda gibi sektörlere yönelik alışveriş sitelerinin faaliyete geçerek perakende e-ticaret sektöründe önemli işlem hacmi oluşmaya başlamıştır (TÜSİAD, 2017, s.45-46). Ancak yine de toplumun çok büyük bir kesimi halen klasik alışveriş yöntemini tercih etmektedir. Özellikle 2015 yılında mobilya sektörüne yönelik olarak yapılmış olan bir araştırmanın bulguları bu durumu açıkça ortaya koymaktadır. Türkiye'de Mobilya Sanayicileri Derneği (MOSDER) tarafından yürütülen söz konusu bu çalıșmanın sonuçlarına göre; araştırmaya katılan örnek kitlede temsil edilen 976 denekten sadece 195 yanıtlayıcının alışveriş işlemini çevrimiçi alışveriş sitelerinden yapmayı tercih ettiği görülmektedir (MOSDER, 2015). Türk halkının çevrimiçi alışverişe karşı bakış açısını göstermesi açısından tipik unsurlar taşıyan bu araştırmanın sonuçları bazı önemli tespitler de ortaya koymaktadır. Buna göre: Türk halkının çevrimiçi alışverişi, klasik alışverișe nazaran tercih etmesindeki en temel unsur satın almayı arzuladığı ürün/hizmeti daha ucuz fiyatlardan bulabilmesidir. Fiyat faktörünün ardından Türk e-ticaret müşterilerinin çevrimiçi alışverişi tercih etmesinde ön plana çlkan ikinci kritik faktörse ürün seçeneğinin ve marka alternatifinin fazla olmasıdır.

Öte yandan araştırma örnekleminde geniş kitleyi oluşturan ve çevrimiçi alışveriş yerine klasik alışverişi tercih eden kitlenin e-ticaret uygulamalarını tercih etmeme gerekçeleriyse şu şekilde sıralanmaktadır (MOSDER, 2015):

- Çevrimiçi alışverişte ürüne dokunarak inceleme imkânının olmaması ve daha önceden internet üzerinden alışveriş deneyiminin olmaması nedeniyle e-ticaret uygulamalarına alışkanlık kazanılmamış olması;

- Ödemeyle ilgili olarak, müşterinin kredi kartı ve diğer kişisel bilgilerini sanal ortamda paylaşmak istememesi;

- Müşterilerin hasarlı, yanlış bir ürün teslim edilmesi riskini üstlenmek istememesi;

- Satın alınacak ürün/hizmetin fiyatının pazarlıksız son fiyat olması; gibi kayglar nedeniyle Türkiye'de insanlar genellikle e-ticaret işlemi yapmaktan çekindiklerini belirtmektedirler.

Bununla birlikte Türkiye'de nihai müşteriye yönelik e-ticaret pazarının gelişmesinin önünde engel teşkil eden temel yapısal sorunlar da şu șekilde ifade edilebilir (Erbaşlar ve Dokur, s.111-120): 
Engin Yılmaz, İbrahim Sarper Karakadılar, "Türkiye'deki Elektronik Ticaret Uygulamalarına Müşteri Gözünden Bakış ve İyileştirme Önerileri”, İstanbul Gelişim Üniversitesi Sosyal Bilimler Dergisi, 6 (1), Nisan 2019, ss. 53-75

- E-ticaret iş modelinin teknolojik altyapısının geliştirilmesi ve siber saldırılara karşı korunmasıyla ilgili yaşanan zafiyetler;

- Şirketin ve müşterilerinin kişisel verilerinin korunmasıyla ilgili yaşanması muhtemel güvenlik sorunları;

- Müşteri güven algısına olumsuz tesir eden, kamuoyu hafızasında yer etmiş e-ticaret sektörüyle ilgili yaşanmış kötü dolandırıcılık deneyimleri;

- Yasal, bürokratik düzenlemelerle ilgili yetersizlikler;

- Müşteri teslimat noktalarına ulaşmada yaşanan lojistik sorunlar;

- Elektronik ödeme sistemlerinin etkin kullanılamaması.

Çalıșmanın sonraki bölümünde, Türkiye'deki hali hazırda e-ticaret alışverişi yapan nihai tüketici kitlesinin, ekonomik olarak beklenilen e-ticaret işlem hacmi potansiyelini gerçekleştirememesiyle ilgili olarak yapılan araştırmanın nasıl yürütüldüğü açıklanmaktadır. Bu doğrultuda, konuyu ele alan bu araștırmanın hangi hedeflere ulaşmak için hangi imkânlar doğrultusunda tasarlanıp uygulandığı detaylı bir şekilde ele alınmaktadır.

\section{ARAŞTIRMANIN METODOLOJISI}

\subsection{Araştırmanın Tasarlanması}

$\mathrm{Bu}$ araştırma bir "tarama modeli" olarak tasarlanmıştır. Tarama modelleri, geçmişte ya da halen var olan bir durumu var olduğu şekilde betimlemeyi amaçlayan araștırma yaklaşımlarıdır. Araștırmaya konu olan olay, birey ya da nesne, kendi koşulları içinde ve olduğu gibi tanımlanmaya çalışılır. Onları herhangi bir şekilde değiștirme, etkileme çabası gösterilmez (Karasar, 2009, s.77). Bu çalışmanın temel hedefi Türkiye'de e-ticaret uygulamalarının işlem hacminin arttırılmasına yönelik çözüm önerilerinin geliştirilmesi olduğundan, bu çalışmada tarama modelinin tercih edilmesi uygun olmaktadır. Böylece, e-ticaret deneyimi yaşamıș müșterilerin davranış özellikleri ortaya konularak, Türkiye'de e-ticaret işlem hacminin artmasının önünde engel teşkil eden nedenlerin tespit edilmesi ve bu doğrultuda çözüm önerilerinin ortaya konulabilmesi arzulanmaktadir.

Bu doğrultuda Türkiye'de internet üzerinden e-ticaret işleminde bulunan insanların davranışlarına etki eden unsurların tespit edilmesi için bir anket formu geliştirilmiştir. Anket formunda deneklere sorulan sorular, öncelikli olarak bu çalışmanın temel amacı doğrultusunda MOSDER araştırmasında (MOSDER, 2015) uygulanmış sınıflamalı ve sıralamalı ölçüm maddelerinin, bu çalışmaya uyarlanmıştır. Bunun dışında "Elektronik Perakendecilikte Kalite (ETailQ)" ölçeğinden de veri toplama sürecinde faydalanılmaktadır (Bulut, 2009, s.257).

Veri toplama aracı olarak biçimlendirilmiş anket formu kullanmak için öncelikle, araştırma yürütülürken temin edilecek verileri içeren soruların araştırmanın hedefine uygun olduğundan emin olunması gerekmektedir. Bu maksatla soruların içerik geçerliliğini doğrulamak maksadıyla anket uygulamasına geçilmeden önce konuya hâkim deneyimli kişilere anket formu inceletilmiştir. Bu ön incelemenin ardından 
Engin Yılmaz, İbrahim Sarper Karakadılar, "Türkiye'deki Elektronik Ticaret Uygulamalarına Müşteri Gözünden Bakış ve İyileştirme Önerileri”, İstanbul Gelişim Üniversitesi Sosyal Bilimler Dergisi,

6 (1), Nisan 2019, ss. 53-75

soruların ifadesiyle ilgili tespit edilen aksaklıklar giderildikten sonra araștırmanın uygulanması aşamasına geçilmiștir.

\subsection{Araştırmanın Evreni ve Örneklem Tespiti}

Araştırmanın yapılandırılması sürecinde örneklem kitlesi belirlenirken homojen (orta gelir düzeyinde, eğitim seviyesi yüksek, gençlerden oluşan bir kitle) bir yapı oluşturmak kaygısı güdülmüş ancak bir yandan da kolay ve etkili veri toplanabilmesi hedeflenmiștir. Bu nedenden ötürü araştırma, erișim kolaylığı bakımından belirli bir coğrafi bölgede yaşayan memur ve işçi kesimine uygulanmıștır. Bu kitlenin tercih edilmesinin temel sebepleri arasında ücretli çalıştıkları için düzenli bir gelire sahip olmaları ve eğitim düzeyi yüksek olduğu için e-ticaret uygulamaları konusunda farkındalıklarının yüksek olması gibi kriterler ön planda tutulmuştur.

Çalışmanın örneklem çerçevesi belirlenirken ana kütle olarak Türkiye coğrafyasında yaşayan tüm e-ticaret müşterileri dikkate alınmıştır. Ancak bu kitlenin tam sayımının mümkün olmaması nedeniyle bazı varsayımlarda bulunarak Türkiye'deki e-ticaret müşterisi olan kitlenin büyüklügünün hesaplanması yoluna gidilmiștir. Bu nedenle öncelikle TÜİK verileri incelenerek 2016 yılı verilerine göre ülke nüfusunun yaklaşık \%61,2 oranındaki kısmının internet kullanmakta olduğu tespit edilmiş ve dolayısıyla internet kullanma imkânı olduğu için bu kitlenin hali hazırda e-ticaret uygulamasını tecrübe etmiş olabileceği yargısına varılmıştır (TÜİK, 2016a). Buna göre, Türkiye nüfusu 2016 yılı verilerine göre 79 milyon 814 bin kişi olarak tespit edildiğinden, yaklaşı 48 milyon 847 bin kişinin Türkiye'de potansiyel e-ticaret müşterisi olduğu varsayımına ulaşılmaktadır. Ancak bu hesaplama yine de tam olarak araştırmanın hedef kitlesini ifade edememektedir. Bu araştırmanın hedefinin çalışan ücretli e-ticaret müşterileri olması nedeniyle, TÜIK (2016b) verilerine bakılarak Türkiye'de ücretle çalışan nüfusun yaklaşı 30 milyon 914 bin kişi olduğu tespit edilmiştir. Bu veriler ışığı altında araştırmanın hedef kitlesini oluşturan ana kütlenin büyüklüğü belirlendikten sonra, \%5 önem düzeyinde ve \%5 hata payı ile ana kütleyi temsil edecek örneklem hacminin büyüklügünün 384 kişiden oluşan denek grubu olması gerektiğine karar verilmiştir (Kurtuluş, 2008, s.88-95).

$\mathrm{Bu}$ nedenle araştırmanın yürütülmesi aşamasında 400 adet anket formu bastırılıp dağıtılmıştır. Geri dönüş olan 330 adet anket formu önce taranmış ve 18 anketin yanıtlayıcılarının hayatlarında hiç e-ticaret deneyimi yaşamamış olması nedeniyle bu anketlerin veri-seti dışında tutulmuştur. Böylelikle neticede araştırmada kullanılacak 312 adet net veriye ulaşılmıştır.

\section{3. Örneklem Grubu ve Örneklemin Araştırmanın Hedefi İçin Uygunluğu}

Araştırma verisinin toplandığı 312 kişiden oluşan örneklem, İstanbul'un Anadolu yakasında özellikle de Maltepe-Pendik ilçelerinde yaşayan bir kitleden oluşmaktadır. Verinin toplandığı örneklemin coğrafi kapsamından ziyade örneklemin "yaşı, eğitim durumu ve medeni durumu" gibi demografik faktörlerinin uygunluğu araștırmanın hedefi doğrultusunda daha kritik unsurlar olarak belirlenmiştir. Nitekim Tablo 1'de 
Engin Yılmaz, İbrahim Sarper Karakadılar, “Türkiye'deki Elektronik Ticaret Uygulamalarına Müşteri Gözünden Bakış ve İyileştirme Önerileri”, İstanbul Gelişim Üniversitesi Sosyal Bilimler Dergisi, 6 (1), Nisan 2019, ss. 53-75

görüldüğü üzere araştırmaya katılan denek grubu internet kullanımı alışkanlığı bakımından araştırmanın amacına uygun bir profil ortaya koymaktadır.

\begin{tabular}{|c|c|c|c|}
\hline & & Kişi & Yüzde \\
\hline \multirow{3}{*}{ Yaş } & 30 yaş ve altı & 115 & 36.9 \\
\hline & 31-40 yaş arası & 144 & 46.1 \\
\hline & 41 yaş ve üzeri & 53 & 17.0 \\
\hline \multirow{2}{*}{$\begin{array}{l}\text { Medeni } \\
\text { Durum }\end{array}$} & Evli & 213 & 68.3 \\
\hline & Bekâr & 99 & 31.7 \\
\hline \multirow{3}{*}{$\begin{array}{l}\text { Eğitim } \\
\text { Durumu }\end{array}$} & Lise ve diğer orta öğretim & 13 & 4.2 \\
\hline & $\begin{array}{c}\text { Üniversite } \\
\text { (Ön lisans ve Lisans) }\end{array}$ & 258 & 82.7 \\
\hline & Yüksek Lisans / Doktora & 41 & 13.1 \\
\hline $\mathrm{n}=\mathbf{3 1 2}$ & & & \\
\hline
\end{tabular}

Tablo 1: Araştırmanın Katılımcı Profili

Özellikle hane halkının gelirini harcama alışkanlığı bakımından değerlendirildiğinde örneklemin \%70'e yakın bölümünün evli yanıtlayıcılardan oluşması önemli olmaktadır. Bununla birlikte örneklemin, yaş skalası olarak genç ve orta yaşlarda, eğitim seviyesi olarak üniversite düzeyinde olması da önemlidir. Her ne kadar ilk bakışta örnek kitle dâhilinde temsil edilen yükseköğrenim mezunu yanıtlayıcıların oranının \%95'den fazla olması örneklem yapısının ana kütlenin heterojenliğini temsilini bozuyor gibi algılansa da aslında tam tersine bu çalışmanın hedef kitlesini tam olarak yansıtan önemli bir detay olarak ele alınmalıdır. Çünkü bu çalışma temelde Türkiye'de eticaret uygulamalarının beklenen potansiyelini ortaya koyamamasında en önemli etken olarak kamuoyuna rol model olan eğitimli kitlenin algı sorununa odaklanmaktadır. $\mathrm{Bu}$ sorun kapsamında etkili yanıt alınacak kitlenin eğitim durumu bakımından yüksek eğitimli kişiler arasından seçilmesi oldukça isabetli olmaktadır. Eğer eğitimli kitle düzenli olarak e-ticaret uygulamalarında yer alıp öncülük ederse zaten toplumun yaşayarak öğrenmesi neticesinde o toplumda yaşayan diğer kitlenin de onları takip ederek e-ticaret işlemlerinde bilinçlenerek katılımlarının artacağı aşikârdır. Bu nedenle araștırmanın amacı kapsamında durum tespiti yapılırken, Türkiye halkının genel profilini yansıtmaktan ziyade bu çalışmada olduğu gibi genç ve eğitimli kitleye odaklanılması daha isabetli olmaktadır.

\section{ANALIZ ve BULGULAR}

\section{1. Örneklem Grubunun E-ticaret Deneyimlerinin Değerlendirilmesi}

Örneklem grubunun e-ticaret deneyimleriyle ilgili araştırma kapsamında toplanan sonuçlar Tablo 2 ve 3'de gösterildiği gibidir. Buna göre araştırma katılımcılarının aylık gelir düzeyine bakıldığında genel olarak 2.000 TL civarında gelir 
düzeyine sahip oldukları görülmektedir. Deneklerin e-ticaret işlemleri için aylık bütçelerinden ayırdıkları miktar ise 500 TL'den daha düşük bir meblağ olduğu gözlenmektedir. Yani örneklem bütününde temsil edilen e-ticaret müșterilerinin verdikleri yanıtlardan anlaşıldığı üzere Türkiye'de bireyler aylık gelirlerinin dörtte birinden (1/4) daha düşük bir oranı e-ticaret alışverişlerine tahsis etmektedirler. Araştırmanın örneklem grubu, internet kullanımına yatkın yüksek eğitimli ve genç-orta yaş kuşağından oluşmasına karşın yine de araştırma sonuçları daha önceden yapılmış sektörel araştırmalara benzer şekilde Türkiye'de e-ticaret işlem yoğunluğunun yüksek olmadığını bir kez daha ortaya koymaktadır.

Diğer bir dikkat çekici sonuç ise örnek kitledeki yanıtlayıcıların bir hafta içerisinde elektronik ticaretle ilgili internet ortamında geçirdikleri sürenin toplamda 30 dakikadan az olmasıdır. Bireylerin e-ticaret sitelerini ziyaret etmelerindeki temel amacının ne olduğu sorulduğundaysa "satın almayı düşündüğü ürünlerle ilgili bilgi edinmek ve diğer alternatif ürün ve markalarla kıyaslamasını yapabilmek" olduğu ifade edilmiştir.

\begin{tabular}{|l|l|l|l|l|l|l|l|l|}
\hline $\begin{array}{l}\text { Aylık } \\
\text { Gelirleri }\end{array}$ & $\mathbf{n}$ & $\mathbf{\%}$ & $\begin{array}{l}\text { E-ticaret } \\
\text { Alışveriş } \\
\text { Bütçesi }\end{array}$ & $\mathbf{n}$ & $\mathbf{\%}$ & $\begin{array}{l}\text { E-ticaret } \\
\text { işlemleri için } \\
\text { harcanan süre }\end{array}$ & $\mathbf{n}$ & $\%$ \\
\hline $\begin{array}{l}1000 \text { TL'nin } \\
\text { altı }\end{array}$ & 84 & 26,9 & $\begin{array}{l}250 \text { TL'nin } \\
\text { alt }\end{array}$ & 178 & 57,1 & $0-30$ dakika & 140 & 44,9 \\
\hline $\begin{array}{l}1000-1999 \\
\text { TL }\end{array}$ & 118 & 37,8 & $\begin{array}{l}250-499 \\
\text { TL }\end{array}$ & 96 & 30,8 & $31-59$ dakika & 57 & 18,3 \\
\hline $\begin{array}{l}2000-2999 \\
\text { TL }\end{array}$ & 66 & 21,2 & $\begin{array}{l}500 \text { TL ve } \\
\text { üzeri }\end{array}$ & 38 & 12,2 & $60-120$ dakika & 71 & 22,8 \\
\hline $\begin{array}{l}3000 \text { TL ve } \\
\text { üzeri }\end{array}$ & 44 & 14,1 & & & & $\begin{array}{l}120 \text { dakikadan } \\
\text { fazla }\end{array}$ & 44 & 14,1 \\
\hline
\end{tabular}

\begin{tabular}{|l|c|c|l|l|l|}
\hline $\begin{array}{l}\text { E-ticaret Sitelerini Ziyaret Etmenin } \\
\text { Temel Amacı * }\end{array}$ & $\mathbf{n}$ & $\mathbf{\%}$ & $\begin{array}{l}\text { E-ticaret Ödeme } \\
\text { Yöntemi }\end{array}$ & $\mathbf{n}$ & $\mathbf{\%}$ \\
\hline $\begin{array}{l}\text { Satın almak istediği ürünle ilgili bilgi } \\
\text { edinmek ve kıyaslama yapmak }\end{array}$ & 241 & 77,2 & Kredi Kartı & 189 & 60,6 \\
\hline $\begin{array}{l}\text { İşlem yaparak bir gereksinimi gidermek için } \\
\text { alışveriş yapmak }\end{array}$ & 89 & 28,5 & $\begin{array}{l}\text { BKM Exp - Sanal Kart - } \\
\text { Mobil Czdn }\end{array}$ & 35 & 11,2 \\
\hline Eğlenmek veya sosyalleşmek & 25 & 7,9 & $\begin{array}{l}\text { Kapıda nakit ödeme - } \\
\text { Banka havalesi }\end{array}$ & 104 & 33,3 \\
\hline
\end{tabular}

\section{- $\mathrm{n}=\mathbf{3 1 2}$.}

- * Birden fazla seçenek ișaretlenebilecek soru

Tablo 2: Örneklemin E-ticaret İşlemleriyle İlgili Davranışları 
Engin Yılmaz, İbrahim Sarper Karakadılar, “Türkiye'deki Elektronik Ticaret Uygulamalarına Müşteri Gözünden Bakış ve İyileştirme Önerileri”, İstanbul Gelișim Üniversitesi Sosyal Bilimler Dergisi, 6 (1), Nisan 2019, ss. 53-75

Ödeme yöntemi olarak en çok tercih edilen uygulamaysa kredi kartıyla ödeme olmuştur. Deneklerin yarısından çoğu $(n=189)$ kredi kartıyla internet üzerinden ödeme yaptıklarını belirtmiştir. Buna karşın e-ticaret işlemleri için;

- Bankalar Birliğinin geliștirdiği “BKM Express",

- Bankaların müşterilerine vermiş oldukları kredi kartlarına bağlı olarak sundukları güvenli internet alışverişine olanak tanıyan "Sanal Kart" ve

- Cep telefonu operatörlerinin e-ticaret işlemleri için geliştirdikleri "MobilCüzdan" uygulamaları gibi diğer ödeme sistemlerinin tercih edilme sıklığıysa sadece $\% 11(\mathrm{n}=35)$ düzeyinde kalmıştır.

Bununla birlikte insanlar kredi kartı bilgilerini internet ortamında paylaşma konusunda oldukça şüpheci yaklaşmakta oldukları da anlaşılmaktadır. Buna göre genellikle $(n=149)$ internet üzerinden yapılan kredi kartı harcamalarında "cep telefonu üzerinden şifre onaylı ödeme" alan yani 3D güvenlikli e-ticaret web sitelerinin tercih edilmekte olduğu gözlemlenmektedir.

Araştırmaya katılan hedef kitleye, bir e-ticaret sitesinden ürün alışverişi faaliyeti (operasyonu) sonunda hangi faktörlere önem vererek yeniden o siteyi tercih etmeyi düşündükleri sorulduğunda ise "satış sonrası hizmet kalitesi" bakımından müşterilerin e-ticaret şirketini öncelikli olarak değerlendirdikleri dikkat çekmektedir. İkinci sıradaki önemli performans kriteri "teslimat süresinin" makul olmasıdır. Bir diğer önemli kriter de "ödeme seçeneklerinin" uygunluğudur.

Bir e-ticaret web-sitesini düzenli olarak tercih etmenizi etkileyen önemli unsurları sıralayın diye sorulduğunda ise tartışmasız bir şekilde ankete katılanların yarısından çoğu (n=173) "güvenilir olmasını" birinci sıraya yerleștirmiștir. İkinci sıradaysa e-ticaret sitesinin satışa koyduğu ürünlerle ilgili yayınladığı bilgilerin "gerçeği yansıtması orijinal gerçek ürünler sunuyor" olması gelmektedir. Müșteriye teslim edilen ürünlerde bir sorun çıkması halinde e-ticaret sitesinin uyguladığı "ürün iade politikası" ise bu kapsamda üçüncü öncelikli unsur olarak yer almaktadır. Bunların dışında "müşteriyi hayal kırıklığına uğratmamak" ve "müşteriye sunduğu ürün/hizmet kalitesinden taviz vermemek" diğer dikkat çekici unsurlar olmuştur.

Alışveriş yaptığınız e-ticaret sitesine güven duymanızda en etkili olan unsur ne diye sorulduğunda: anket katılımcılarının yarısından çoğu (n=183) e-ticaret firmasının "kamuoyu tarafından bilinen, markalaşmış, arkasında ciddi kurumsal firmaların olduğu" web-sitelerine güven duyduklarını belirtmişlerdir. İkinci önemli faktörse $\% 25$ oranında yanıtlayıcılar "kendi şahsi araştırmaları neticesinde" tercih etikleri e-ticaret sitesine güven duygusunun oluştuğunu belirtmişlerdir.

E-ticaret sitelerinin potansiyel müşterileri, internet üzerinde gezinirken incelemekte oldukları web-sayfasında ansızın beliren herhangi bir e-ticaret firmasının reklam amaçlı "pop-up" uygulamalarına tepkilerinin ne olduğu sorulduğunda: bu uygulamanın firmaların hedefledikleri amacına ulaşmadığı görülmektedir. Deneklerin neredeyse yarıya yakını ( $\mathrm{n}=141)$ bu uygulamanın "kesinlikle sinirlerini bozduğunu ve o firmadan alışveriş yapmayı hiç düşünmediklerini” belirtmişlerdir. Buna karşın bu beliren reklam sayfasını tıklayıp açarak "inceleyip eğer ihtiyacı olan bir ürün varsa alırım" diyen kesimse deneklerin sadece \%11'ini (n=35) içermektedir. 
İnternet üzerinden müşterilerin işlem yaptıkları sektörlerin öncelik sırasına bakıldığında "bankacılık işlemleri" açık ara öne çıkmaktadır. Bankacılık işlemlerinin hemen ardından tekstil-moda sitelerinden "kıyafet alışverişi” ikinci sırada yer almaktadır. Bu iki sektörün ardından daha orta düzeyde işlem sıklığı olan "ev eşyası alışverişi" ile şehir dışı ulaşım için "bilet satın alınması" ve turistik amaçlı "seyahatkonaklama rezervasyonu yapılması" işlemleri gelmektedir.

\begin{tabular}{|c|c|c|c|c|c|}
\hline $\begin{array}{l}\text { İnternet üzerinden } \\
\text { müşterilerin işlem } \\
\text { yaptıkları sektörlerin } \\
\text { öncelik sırası* }\end{array}$ & - $\mathbf{n}$ & - $\%$ & $\begin{array}{l}\text { E-ticaret web- } \\
\text { sitesini düzenli } \\
\text { olarak tercih } \\
\text { etmenizi } \\
\text { etkileyen } \\
\text { unsurlar* }\end{array}$ & $\begin{array}{ll}\cdot \mathrm{n} \\
\end{array}$ & - $\%$ \\
\hline Bankacılık İșlemleri & - 140 & - 44,9 & Güvenilir Olması & - 173 & - 55,4 \\
\hline $\begin{array}{l}\text { Tekstil Moda } \\
\text { Sitelerinden Kıyafet } \\
\text { Alışverişi }\end{array}$ & - 101 & - 32,4 & $\begin{array}{l}\text { Satışa Koyduğu } \\
\text { Ürünlerin Orijinal } \\
\text { Olması }\end{array}$ & - 61 & - 19,6 \\
\hline Ev Eşyası Alışverişi & - 15 & - 4,8 & $\begin{array}{l}\text { Ürünlerin İadesinin } \\
\text { Kabulünün } \\
\text { Kolaylığı }\end{array}$ & $\begin{array}{ll} & 40\end{array}$ & - 12,8 \\
\hline $\begin{array}{l}\text { Şehir Dışı Ulaşım için } \\
\text { "otobüs/uçak bileti satın } \\
\text { alınması" }\end{array}$ & - 7 & - 2,2 & $\begin{array}{l}\text { Tüketiciyi Hayal } \\
\text { Kırıklığına } \\
\text { Uğratmaması }\end{array}$ & - 13 & - 4,2 \\
\hline $\begin{array}{l}\text { Turistik Konaklama } \\
\text { Rezervasyonu yapılması }\end{array}$ & - 9 & - 2,9 & $\begin{array}{l}\text { Müșteriye Sunduğu } \\
\text { Ürün/Hizmet } \\
\text { Kalitesi }\end{array}$ & - 14 & - 4,5 \\
\hline
\end{tabular}

\begin{tabular}{|l|l|l|}
\hline E-ticaret sitesinde işlem yapmak için güven duymaya etkili olan unsurlar & $\mathbf{n}$ & $\mathbf{\%}$ \\
\hline $\begin{array}{l}\text { Kamuoyu tarafından bilinen, markalaşmış, arkasında ciddi kurumsal firmaların } \\
\text { olduğu web-siteleri }\end{array}$ & 183 & 58,7 \\
\hline Kendi yaptığı şahsi araştırmalar neticesinde & 77 & 24,6 \\
\hline Yakın çevremdeki ve sosyal medyadaki insanların yorumlarından ötürü & 44 & 14,1 \\
\hline Reklamlar & 8 & 2,6 \\
\hline
\end{tabular}

Tablo 3: Örneklemin E-ticaret Siteleriyle İlgili Deneyimleri

\subsection{Elektronik Perakendecilikte Kalite (ETailQ) Ölçeği ile İlgili Analizler}

Araştırmanın bu bölümünde Wolfinbarger ve Gilly (2003) tarafından geliştirilen ve daha önceki yıllarda da Türkiye'de Bulut (2009, s. 256-259) tarafından çalışılmış olan "Elektronik Perakendecilikte Kalite (ETailQ)" ölçeğiyle toplanan veriler analiz edilerek incelenmektedir. Öncelikle anket formunun ön-testi aşamasında ölçeğin daha önce Bulut 
Engin Yılmaz, İbrahim Sarper Karakadılar, "Türkiye'deki Elektronik Ticaret Uygulamalarına Müşteri Gözünden Bakış ve İyileştirme Önerileri”, İstanbul Gelişim Üniversitesi Sosyal Bilimler Dergisi,

6 (1), Nisan 2019, ss. 53-75

(2009) tarafından Türkçeye çevrilmiş orijinal 14 maddenin hepsi kullanılmıştır. Ancak ön-test aşamasında bu araştırmaya katılan yanıtlayıcılar tarafindan tam olarak anlaşllamadığı düşünülen 3 soru maddesinin araştırmada kullanılacak nihai anket formundan çıkarılmasına karar verilmiştir. Orijinal ölçekte bulunup bu çalışmaya dâhil edilmeyen anket soruları şunlardır:

- İnternet üzerinden alışveriş yapacağım web sitesinin seçiminde, sitede olması gerektiği kadar (ne az ne de çok) kişiye özgü uygulamaların bulunması önemlidir;

- İnternet üzerinden alışveriş yapacağım web sitesinin seçiminde, sitede kendimi güvende hissetmem önemlidir;

- İnternet üzerinden alışveriş yapacağım web sitesinin seçiminde, sitenin güvenlik donanımı etkilidir.

Bu çıkarılan sorular yerine araştırmacılar tarafından yazılan:

- İnternet üzerinden alışveriş yapacağım web sitesinin seçiminde, aradığım ürün veya hizmetin uygun koşullarda sitede bulunması önemlidir;

- İnternet üzerinden alışveriş yapacağım web-sitesinin oradan alışveriş yapmamı özendirici kampanyalar (promosyon) yapıyor olması önemlidir;

soruları eklenmiştir. Elektronik perakendecilikte kalite (ETailQ) ölçeğinin değerlendirilmesi için veri-setinde müşterilerin öncelikle işlem yaptıklarını belirttikleri e-ticaret perakendeciliğiyle direk ilgili olan "giyim, ev eşyası, turizm seyahat ve konaklama" sektörlerinde işlem yapan yanıtlayıcıların anketleri dikkate alınmıștır. Söz konusu bu veri saflaştırma işlemiyle bankacılık işlemlerine verilen yanıtların ölçeğin yapısını bozmaması ve araştırmanın temel amacından uzaklaşılmaması sağlanmaktadır. Neticede ETailQ ölçeğinin analiz edileceği toplam 132 gözlemden oluşan veri setine ulaşılmıştır.

\subsubsection{ETailQ Ölçek Maddelerinin Ortalama Değerleri}

Veri setinin tanımlayıcı analiz sonuçları incelendiğinde en dikkat çekici sonuç e-ticaret müşterileri için en kritik ölçüm maddelerinin:

- İnternet üzerinden alışveriş yapacağım web sitenin seçiminde, kişisel bilgilerimin site tarafından tam olarak korunması önemlidir.

- İnternet üzerinden alışveriş yapacağım web sitesinin seçiminde, siteden ne sipariș edersem o ürünün teslim edileceği güvencesi etkilidir.

Her iki sorunun ortalama değeri 4,83 çlkmıştır. Geriye kalan diğer 11 maddenin ise ortalama değerlerinin en düşüğü 4,43 en yükseği ise 4,73 olarak bulunmuştur. Bu sonuçtan anlaşılacağı üzere anket yanıtlayıcıları için e-ticaret ile ilgili öncelikli unsur kişisel bilgilerinin ilgisiz üçüncü şahısların eline geçmesi korkusudur. Bu kaygının giderilebilmesiyse ancak toplumun e-ticaret teknolojik altyapısının güvenliğine ilişkin tereddütsüz inanabileceği bir güvencenin verilebilmesine bağlıdır. Yine benzer şekilde araştırma örnekleminin verdiği yanıtlardan anlaşılacağı üzere müşteriler ürün/hizmet sipariş ettiği e-ticaret firması tarafından dolandırılıp-kandırılmayacağından emin olmak istemektedir. Bu amaçla da Türk e-ticaret pazarında bir sektörel sertifikasyon güvence sisteminin oluşturulması şarttır. 
Engin Yılmaz, İbrahim Sarper Karakadılar, “Türkiye'deki Elektronik Ticaret Uygulamalarına Müşteri Gözünden Bakış ve İyileştirme Önerileri”, İstanbul Gelişim Üniversitesi Sosyal Bilimler Dergisi,

6 (1), Nisan 2019, ss. 53-75

\subsubsection{ETailQ Ölçeğinin Faktör Analiz Sonuçları}

$\mathrm{Bu}$ aşamada öncelikle veri-setinin faktör analizine uygunluğunu görmek amacıyla "Kaiser-Meyer-Olkin (KMO)" katsayısı hesaplanmış ve "Barlett testi" gerçekleştirilmiştir. Hesaplamalar sonucunda KMO değerinin 0,89 olduğu görülmüștür. Ayrıca Barlett testi de $\mathrm{p}<0,01$ düzeyinde anlamlı çıkmıştır. Dolayısıyla araştırma kapsamında temin edilen veri setinin faktör analizi için uygun olduğu anlaşılarak, faktör analizi gerçekleștirilebilmiştir. Faktör analizi yapılırken çıkarım yöntemi olarak "Temel Bileșenler Analizi (Principal Component Analysis)” yöntemi kullanılmıștır. Faktör sayısı belirlerken özdeğeri 1'den yüksek olan bileșenler ayrı birer faktör olarak kabul edilmiştir. Bu kritere dayalı olarak yapılan analiz sonucunda, analize dâhil edilen 13 ölçüm sorusu 2 farklı faktöre yüklenmiştir ve sorular ve faktör yükleri Tablo 4'de gösterilmiştir.

Keşifsel faktör analizi uygulaması sonucunda 13 ölçüm maddesinin 12 tanesi iki farklı gruba güçlü faktör yükleriyle yüklenmiştir. Ölçeğe daha sonradan bu çalışma kapsamında ilave edilmiş olan "e-ticaret sitesinden alışveriş yapmak için özendirici kampanyalar düzenliyor olması önemlidir" soru maddesi kabul edilebilir eşik değer olan 0,5 kriterinin çok altında yüklendiği için ölçeğe dâhil edilebilmesi mümkün olmamıştır. Yine bu çalışma kapsamında ölçüm maddesi olarak yeni ilave edilen "e-ticaret sitesinde uygun ürün/hizmet bulunabilir olması önemlidir" maddesiyse yüklenilmesi beklenilen ilgili faktör grubuna güçlü bir şekilde yüklenmiștir.

Yapılan faktör analizi neticesinde ortaya çıkan "e-ticaret web-sitesinin cazibesi" ve "e-ticaret web-sitesine duyulan güven" değișkenlerinin güvenirliğini test etmek amacıyla, her bir bileşeni oluşturan ölçüm maddelerini içeren Cronbach's Alfa güvenirlik katsayıları hesaplanmıştır. Tablo 4'de gösterildiği gibi yapılan hesaplama sonucunda her iki faktör grubunun da eşik değer olan 0,7 kriterinin üzerinde sonuçlar vererek yeterli güvenirliğe sahip olduğu görülmüştür.

\begin{tabular}{|l|l|l|}
\hline Ölçüm Maddeleri & $\begin{array}{l}\text { E-ticaret } \\
\text { Web } \\
\text { Sitesinin } \\
\text { Cazibesi }\end{array}$ & $\begin{array}{l}\text { E-ticaret } \\
\text { Web Sitesine } \\
\text { Duyulan } \\
\text { Güven }\end{array}$ \\
\hline Internet üzerinden alıșveriș yapacağım web-sitesinin seçiminde,........... & $\begin{array}{l}\text { Cronbach' } \\
\text { s Alpha } \\
, 85\end{array}$ & $\begin{array}{l}\text { Cronbach's } \\
\text { Alpha } \\
, 86\end{array}$ \\
\hline o sitenin kapsamlı bilgi sunması etkilidir. &, 626 &, 723 \\
\hline sitede işlem yapmanın kolay olması gibi görsel unsurlar etkilidir. &, 728 & \\
\hline $\begin{array}{l}\text { aradığım ürün veya hizmetin uygun koşullarda sitede bulunması } \\
\text { önemlidir. }\end{array}$ &, 787 &, 686 \\
\hline $\begin{array}{l}\text { sunulan ürünlerin web-sitesi tarafindan etkili (doğru) bir şekilde } \\
\text { tanıtılması önemlidir. }\end{array}$ &, 587 & \\
\hline sitede işlem yaparken zaman kaybına yol açmaması etkilidir. & & \\
\hline sitenin sunduğu ürün çeşitliliği önemlidir. & & \\
\hline
\end{tabular}


Engin Yılmaz, İbrahim Sarper Karakadılar, “Türkiye'deki Elektronik Ticaret Uygulamalarına Müșteri Gözünden Bakıș ve İyileștirme Önerileri”, İstanbul Gelișim Üniversitesi Sosyal Bilimler Dergisi,

6 (1), Nisan 2019, ss. 53-75

\begin{tabular}{|c|c|}
\hline $\begin{array}{l}\text { oradan alışveriş yapmamı özendirici kampanyalar düzenliyor olması } \\
\text { önemlidir. }{ }^{\circledR}\end{array}$ & Düşük Faktör Yükü \\
\hline siteden ne sipariş edersem o ürünün teslim edileceği güvencesi etkilidir. &, 544 \\
\hline siteden aldığım ürünün söz verilen zamanda teslim edilmesi önemlidir. & ,689 \\
\hline kişisel bilgilerimin site tarafindan tam olarak korunması önemlidir. & ,667 \\
\hline $\begin{array}{l}\text { sitenin müşteri odaklı olup insanların beklentilerini karşılamaya hazır ve } \\
\text { istekli olması önemlidir. }\end{array}$ & ,714 \\
\hline $\begin{array}{l}\text { bir sorunum olduğunda web-sitesinin o sorunu çözmek için çaba } \\
\text { göstermesi önemlidir. }\end{array}$ & ,778 \\
\hline şikayetlerin site tarafından tam zamanında cevaplanması önemlidir. & ,800 \\
\hline \multicolumn{2}{|c|}{$\begin{array}{l}\mathbf{n = 1 3 2 .} \\
\text { ®Faktör yükü ve ifadesi koyu renkle yazılan ölçüm maddesi düşük faktör yüküyle yüklendiği için } \\
\text { analizden çıkarılmıştır. } \\
\text { Çıkarım Yöntemi: Temel Bileşenler Analizi, Döndürme Yöntemi: Kayser Normalizasyonu ile Varimax } \\
\text { KMO: 0,888 Barlett testi ( Ki-Kare: 810,175, Serbestlik Derecesi:66, Anlamlılık: 0,000). } \\
\text { Açıklanan Varyans \%59,56 olarak gerçekleşmiştir. }\end{array}$} \\
\hline
\end{tabular}

Tablo 4: Elektronik Perakendecilikte Kalite (EtailQ) Ölçeği Faktör Yapısı

\subsection{3. Ürün/hizmet satın alan müşteriler için ETailQ ölçüm maddelerinin ilişkilerinin incelenmesi}

Çalışmanın önceki aşamalarında örneklemin e-ticaret işlemleriyle ilgili deneyimleri incelenirken, araştırma katılımcılarının işlem yaptıkları sektörler baz alındığında bankacılık işlemlerini uygulayanlar bir grup, ürün/hizmet satın almayı öncelikli olarak tercih edenler ise bir diğer grup olarak sınıflandırılmıştır (Bknz Tablo 3). Bu çalışmanın temel amacı e-ticaret ile perakende alışveriş yapan kitlenin Türkiye'de alışveriş hacminin artması için önem verdikleri unsurların belirlenmesi olduğu için ETailQ ölçeğinin ölçüm maddelerinin arasındaki korelasyon ilişkisi sadece bu boyut dikkate alınarak incelenmektedir.

\begin{tabular}{|c|c|c|c|c|c|c|}
\hline Ölçüm Maddesi & 1 & 2 & 3 & 4 & 5 & 6 \\
\hline \multirow{2}{*}{ 1-sitenin kapsamlı bilgi sunması } & & & & & & \\
\hline & 1 & & & & & \\
\hline \multirow{2}{*}{ 2-sitede işlem yapmanın kolay olması } & & & & & & \\
\hline &, $478^{* *}$ & 1 & & & & \\
\hline \multirow{2}{*}{$\begin{array}{l}\text { 3-aranılan ürün/hizmetin uygun } \\
\text { koşullarda bulunması }\end{array}$} & & & & & & \\
\hline &, $628^{* *}$ &, $598^{* *}$ & 1 & & & \\
\hline \multirow{2}{*}{$\begin{array}{l}\text { 4-ürünlerin etkili (doğru) bir şekilde } \\
\text { tanıtılması }\end{array}$} & & & & & & \\
\hline &, $502^{* *}$ &, $404^{* *}$ &, $562^{* *}$ & 1 & & \\
\hline \multirow{2}{*}{$\begin{array}{l}\text { 5-sitede işlem yaparken zaman } \\
\text { kaybetmemek }\end{array}$} & & & & & & \\
\hline &, $407^{* *}$ &, $549 * *$ & ,605** &, $537^{* *}$ & 1 & \\
\hline
\end{tabular}




\begin{tabular}{|l|l|l|l|l|l|l|}
\hline Ölçüm Maddesi & $\mathbf{1}$ & $\mathbf{2}$ & $\mathbf{3}$ & $\mathbf{4}$ & $\mathbf{5}$ & $\mathbf{6}$ \\
\hline \multirow{2}{*}{ 6-sitenin sunduğu ürün çeșitliliği } & & & & & & \\
\cline { 2 - 8 } &, $318^{* *}$ &, $337^{* *}$ &, $344^{* *}$ &, $450^{* *}$ &, $392^{* *}$ & $\mathbf{1}$ \\
\hline
\end{tabular}

Tablo 5: E-Ticaret Web-Sitesinin Cazibesiyle İlgili Ölçüm Maddeleri Arasındaki Korelasyon İlişkileri

Tablo 5'de sunulduğu üzere e-ticaret işlemlerinde ürün/hizmet siparişine öncelik veren 132 denek olduğu görülmektedir. Elektronik Perakendecilikte Kalite (ETailQ) Ölçeğinin e-ticaret web-sitesinin cazibesi boyutuyla ilgili korelasyon ilişkisine bakıldığında, ölçüm maddelerinin hepsinin aralarında $(\mathrm{p}<0,01)$ düzeyinde istatistiksel olarak anlamlı bir ilişki içinde olduğu görülmektedir. Analiz sonuçlarına bakıldığında "internet sitesinde aranılan ürün/hizmetin uygun koşullarda bulunmasının” kritik bir unsur olduğu dikkat çekmektedir. Bu bağlamda özellikle "internet sitesinin kapsamlı bilgi sunması" ( $r=, 628)$ ve "internet sitesinde işlem yaparken gereksiz zaman kaybetmemenin" $(r=, 605)$ bu kritik unsur ile yüksek korelasyon ilişkisinin tespit edilmesi, bu tür siteler tasarlanırken esas dikkat edilecek unsurların neler olduğunu göstermesi açısından önemli bir bulgu olmaktadır.

\begin{tabular}{|c|c|c|c|c|c|c|}
\hline Ölçüm Maddesi & 1 & 2 & 3 & 4 & 5 & 6 \\
\hline \multirow{2}{*}{$\begin{array}{l}\text { 1- siteden ne sipariş edersem o ürünün } \\
\text { teslim edileceği güvencesi }\end{array}$} & & & & & & \\
\hline & 1 & & & & & \\
\hline \multirow{2}{*}{$\begin{array}{l}\text { 2- siteden aldığım ürünün söz verilen } \\
\text { zamanda teslim edilmesi }\end{array}$} & & & & & & \\
\hline & ,444** & 1 & & & & \\
\hline \multirow{2}{*}{$\begin{array}{l}\text { 3- kişisel bilgilerimin site tarafından } \\
\text { tam olarak korunması }\end{array}$} & & & & & & \\
\hline & ,459** &, $643^{* *}$ & $\mathbf{1}$ & & & \\
\hline \multirow{2}{*}{$\begin{array}{l}\text { 4- sitenin müşteri odaklı olup } \\
\text { beklentilerini karşlamaya hazır ve } \\
\text { istekli olması }\end{array}$} & & & & & & \\
\hline &, $516^{* *}$ &, $473^{* *}$ & ,505** & 1 & & \\
\hline \multirow{2}{*}{$\begin{array}{l}\text { 5- bir sorunum olduğunda web-sitesinin } \\
\text { o sorunu çözmek için çaba göstermesi }\end{array}$} & & & & & & \\
\hline & ,400** &, $307^{* *}$ & ,417** & ,619** & 1 & \\
\hline \multirow{2}{*}{$\begin{array}{l}\text { 6- şikâyetlerin site tarafından tam } \\
\text { zamanında cevaplanması }\end{array}$} & & & & & & \\
\hline & ,562** & ,637** & ,654** & ,594** & ,529** & 1 \\
\hline
\end{tabular}

Tablo 6: E-Ticaret Web-Sitesine Duyulan Güvenle İlgili Ölçüm Maddeleri Arasındaki Korelasyon İlişsileri

Tablo 6'da görüldüğü üzere Elektronik Perakendecilikte Kalite (ETailQ) Ölçeğinin e-ticaret sitelerine duyulan güven boyutuyla ilgili korelasyon ilişkisine bakıldığında, ölçüm maddelerinin hepsinin aralarında $(\mathrm{p}<0,01)$ düzeyinde istatistiksel olarak anlamlı bir ilişkinin olduğu görülmektedir.

Ürün/Hizmet Siparişinde e-ticaret sitelerine duyulan Güven Boyutu kapsamında üç unsurun aralarında güçlü bir ilişki olduğu dikkat çekmektedir. Bunlar: 
Engin Yılmaz, İbrahim Sarper Karakadılar, “Türkiye'deki Elektronik Ticaret Uygulamalarına Müşteri Gözünden Bakış ve İyileştirme Önerileri”, İstanbul Gelişim Üniversitesi Sosyal Bilimler Dergisi,

6 (1), Nisan 2019, ss. 53-75

- İnternet üzerinden alışveriş yapacağım web sitesinin seçiminde, siteden aldığım ürünün söz verilen zamanda teslim edilmesi önemlidir.

- İnternet üzerinden alışveriş yapacağım web sitesinin seçiminde, kişisel bilgilerimin site tarafından tam olarak korunması önemlidir (yukarıdaki unsur ile korelasyon katsayısı; $r=$,643).

- İnternet üzerinden alışveriş yapacağım web sitesinin seçiminde, müșteri şikâyetlerinin site tarafından tam zamanında cevaplanması önemlidir (yukarıdaki diğer iki unsur ile korelasyon katsayıları sırasıyla; $r=$,637 ve $r=, 654$ ).

Nihai müşterilere ürün/hizmet pazarlaması yapan perakende e-ticaret şirketlerinin alışveriş güvenliği açısından hedef kitlelerinin yukarıda vurgulanan algılarına hitap edecek uygulamalar peşinde olması gerekmektedir. $\mathrm{Bu}$ nedenle operasyonel anlamda e-ticaret firmalarının ürün teslimatı konusunda stratejik iş ortaklarını doğru seçmeleri onlarla yüksek müşteri hizmet düzeyi yaratacak bir iş modeli tasarlamaları gerekmektedir. Bununla birlikte e-ticaret web sitelerinin adaletlihakkaniyetli bir şekilde müşteri şikâyetlerini ele alma politikalarını belirleyerek, nitelikli personel ile müşteri şikâyetlerine etkili çözümler bulma yoluna gitmeleri faydalı olacaktır. Bir diğer kritik faktör olan müşterilerin kişisel bilgilerinin etkin bir şekilde kusursuzca korunmasıysa ilgili e-ticaret şirketinin almış olduğu teknolojik tedbirleri hedef müşteri kitlesine açıklayarak bilgilendirmek için çeşitli pazarlama iletişimi uygulamalarına önem vermelerini zorunlu kılmaktadır.

\section{SONUÇ ve ÖNERÍLER}

Türkiye'de e-ticaret uygulamasını tecrübe etmiş, kendi gelirini kazanan maaşlı çalışan kitleyi hedefleyerek yapılan bu araştırmanın bulgularının ortaya koyduğu üzere, araştırma katılımcılarının genel olarak e-ticaret işlemlerine bakış açısının şüpheci olduğu görülmektedir. Bu nedenden olsa gerek araştırmaya katılan kitlenin e-ticaret için günlük yaşamlarından ayırdıkları vakit ve alışveriş bütçelerinden ayırdıkları payın oldukça düşük olduğu gözlemlenmektedir. Araştırmaya katılan denek kitlesinin verdiği yanıtlardan, e-ticaret web sitelerinin ziyaret edilmesindeki temel unsurun alışveriş yapmak yerine, ürün/hizmet ile ilgili bilgi almak olduğu anlaşılmaktadır. Bütün bunlar değerlendirildiğinde araştırma katılımcıları için halen geçerli olan alışveriş yönteminin fiziksel olarak mağazaya gitmek ve orada kendi kontrolü altında o anda alışveriş işlemini gerçekleştirmek olduğu anlaşılmaktadır.

Görüldüğü üzere Türkiye'de e-ticaret alışveriş hacmini arttırmak, e-ticaret uygulamalarının sağlamış olduğu operasyonel verimlilik ile etkin müşteri memnuniyeti sağlanarak toplumsal refahın ve hayat kalitesinin artması için daha kat edilmesi gereken çok mesafe vardır. Konu bu kapsamda ele alındığında Türkiye'deki e-ticaret potansiyelini gerçeğe dönüştürmek için sektör temsilcisi kurumlara önemli görevler düşmektedir. Çünkü şu an için e-ticaret işlemlerinin pasif-çekingen tarafı olan müșteri kitlesinin, harekete geçerek e-ticaret işlemlerinde daha fazla aktif taraf olmaya başlamaları için e-ticaret firmalarının ayrı ayrı bireysel çaba göstermeleri yerine sektör olarak hep birlikte hareket etmeleri gerekmektedir. Her ne kadar, Türkiye'de faaliyet 
gösteren kurumsal yönetilen ve pazar payı bakımından sektörün öncü firmalarını bünyesinde barındıran "Elektronik Ticaret İşletmecileri Derneği- ETiD" on yıldan uzun süredir bu doğrultuda çalıșmaktaysa da bu derneğin sektörün potansiyel müșterilerinin güven algısını arttırmaya yönelik çabaları henüz yeterli düzeye ulaşabilmiş değildir. Derneğin web sayfasında deklare edilen kurumsal amaçları ve hali hazırda yürüttükleri faaliyetlere bakıldığında derneğin potansiyel müşterilerin kaygılarını çözüme kavuşturup onları bilgilendirmek yerine daha çok sektör odaklı faaliyetlerde bulundukları görülmektedir (ETID, 2018). Tabi ki derneğin sektör odaklı çalışması doğaldır, ancak sektörün sürdürülebilirliğini ve büyümesini sağlamak adına dernek tarafından yürütülen "Kişisel Verilerin Saklanması" ve "Hukuki Altyapının Oluşturulması" gibi konularda yapmış oldukları ciddi çalışmaların bir an önce sonlandırılarak kamuoyunun etkili biçimde bilgilendirilmesi gerekmektedir. Özellikle, "derneğin iş etiğine uygun hareket etmeyen üyelerine idari yaptırımlar uygulaması" ve/veya "sektörde art niyetli faaliyet göstererek ticari ahlak sınırları dışında çalışan firmaları içeren kara-listenin oluşturulup sürekli güncellenerek yayınlanması" gibi kısa vadede hızla uygulanabilecek etkili tedbirlerle potansiyel müşterilerin sektöre olan güven algısının artması sağlanmalıdır.

$\mathrm{Bu}$ doğrultuda düzenleyici olarak Türkiye Cumhuriyeti Gümrük ve Ticaret Bakanlığına da çok kritik görev düşmektedir. Bu amaçla bakanlık tarafından geliştirilen "Elektronik Ticaret Bilgi Sistemi (ETBİS)" 2018 yılı başı itibariyle hizmete girmiştir. Ancak bu sistem direk olarak sektörü düzenlemekten ziyade sektörel verilerin tek elden doğru ve sistemli olarak kayıt altına alınmasını amaçlamaktadır. Müşteri açısından bu sistemin getirdiği yenilik ise sadece ticari sicil anlamında kayıtlı kurumsal e-ticaret şirketlerini sorgulayabilecekleri (eticaret.gov.tr) internet sitesini kullanabilmeleridir (GTB, 2018). Bu nedenle ETBIS uygulaması ancak dolaylı yoldan vatandaşların e-ticaret sektörüne duydukları güven algısına kısıtlı bir șekilde destek olabilecektir. Hâlbuki bakanlık:

- e-ticaret iş sürecinde yer alan kargo ve lojistik şirketlerinin etkinliğinin takip edilmesi,

- e-ticarete konu olan ürün/hizmetin üretim yeri, deposu gibi tesislerinin denetlenmesi,

- ürün/hizmetin sağlık, kalite güvence onaylarının verilmesi ve

- ödeme sürecinin uygunluğunun onaylanması

şeklinde direk olarak sektörün işleyişinde düzenleyici bir rol alması gerekir. Böylelikle sektörün daha doğru işlemesi ve etkinliğinin artması sağlanacaktır.

Araştırma bulgularına göre müşterilerin alışveriş yaptıkları web-sitesinin operasyonel performansını değerlendirirken öne çıkardıkları kriterlerin "satış sonrası hizmet kalitesi" ve "makul teslimat süresi" olduğu tespit edilmiştir. Bu sonuçlar da mikro düzeyde her bir firmanın kendi başına çaba göstermesindense yukarıda değinildiği gibi sektörel bazda makro düzeyde alınması gereken önlemlerin önemini bir kez daha ortaya koymaktadır.

Özellikle üst düzey müşteri hizmeti sunabilmek için e-ticaret şirketinin; kurumsal bir yapıda, yeterli kaynakları olan ve stratejik iş ortaklarıyla birlikte gerekli 
organizasyonları yerine getirebilme becerisinin olması gerekmektedir. Bu doğrultuda eticaret şirketlerinin kurumsallaşma seviyesini yukarıya çıkarmak için hukuksal olarak bir yetkilendirme sisteminin oluşturulması gerekebilir. Örneğin; resmi olarak bir şirketin e-ticaret yapabilmesi için yetki belgesi alması ve bu belgeye sahip olabilmek için ise "bir güvence bedeli veya teminat mektubunu, yetki belgesini dağıtan ilgili resmi kuruma yatırması șeklinde ișleyen” bir sistem olușturulabilir. Böylelikle müșteri şikâyetlerinde hukuki yollardan bir geri ödeme veya tazminat kararı çıktığında bu güvence bedeli üzerinden müșterinin hakkı olan tazminat bedelinin kolaylıkla tahsil edilebileceği bir sistem geliştirilebilir. Bu sayede hem müşterilerin kișisel e-ticaret deneyimlerine yönelik garanti-güvence sistemi olușturulmuş olur, hem de e-ticaret firmalarının sunduğu müşteri memnuniyeti performansı dönemsel olarak kolaylıkla şeffaf bir şekilde izlenebilir.

Bununla beraber, makul teslimat süresi performansı için de sektör derneği ETiD ile sektörün büyük ölçekli öncü firmalarının, dağıtım konusunda sektörün gereksinimlerine ve ülkenin ekonomik-ticari gerçeklerine uygun yeni bir yapılanma içine gitmeleri faydalı olabilir. Bu amaçla sektörün kendi kontrolünün altında, kendi lojistik merkezini açması sayesinde dağıtım ve teslimat işlemlerinde e-ticaret firmalarının verimliliğinin ve müşterilerin de arzu ettiği düzeyde teslimat performansının artması sağlanabilir. Ama tabi ki böyle bir oluşum öncesi sektör temsilcilerinin sinerjik bir iş birlikteliği içerisinde olması ve profesyonel bir yaklaşımla bu süreci organize edip yönetmesi șarttır.

Araştırmaya katılan kitlenin internet üzerinden işlem yaptıkları sektörlerin öncelik sırasına bakıldığında ise bankacılık işlemlerinin açı ara öne çıktığı dikkat çekmektedir. Her ne kadar e-ticaret denildiğinde ilk akla gelen unsur ürün/hizmet sipariş etmek olsa da, araştırmanın denekleri tarafından internet üzerinden yapmış oldukları işlemlerde bankacılık ve finans işlemlerinin çok daha yoğun bir şekilde kullanıldığı görülmektedir. İnternet üzerinden yapılan işlemlerde güvenliğin önemliliği açısından ise bankacılık işlemlerinin daha fazla risk unsuru taşıyan bir süreç olduğu tartışılmaz bir gerçektir. Bu nedenle Türkiye'de e-ticaret işlemlerinin teknolojik altyapısıyla ilgili yerli siber güvenlik tedbirlerinin alınması şarttır. Makro açıdan bakıldığında, bu doğrultuda iki kritik unsurun geliştirilerek siber güvenliğin sağlanması zorunluluğu ortaya çıkmaktadır. Bunlardan ilki “Google, Microsoft, Apple-Safari, Yandex ve Mozilla" gibi dünyanın dev internet gruplarına ait olan tarayıcllara alternatif olarak milli bir tarayıcının geliştirilmesinin gerekliliğidir. Bu amaçla 2017 senesinde testine başlanılan ve 2018 yılı sonlarına kadar tam olarak faaliyete geçmesi beklenen "Geliyoo" internet tarayıcısının, Türkiye'de milli siber güvenliğin sağlanabilmesi için önemli bir rol oynaması beklenmektedir (NTV, 2017). İkinci kritik unsur ise "Güvenli Giriş Katmanı (SSL)" sertifika sağlayıcılarının küresel anlamda bir tekel şeklinde çalışmasından kaynaklanan güvenlik sorunlarıdır. Teknik anlamda bakıldığında bu küresel tekelin Türkiye'deki e-ticaret işlemlerine ait tüm bilgilere sahip olmasının yanında, operasyonel etkinlik bakımından ise sertifika temin etme sürecinde zaman kaybı yaşanmasına ve Türk e-ticaret firmalarının maliyetlerinin artmasına neden olmaktadır. Buna karşın ortaya çıkabilecek herhangi bir güvenlik sorunundaysa, bu küresel sertifika sağlayıcılarının Türkiye'ye karşı sorumluluklarını düzenleyen bir hukuki yaptırım 
Engin Yılmaz, İbrahim Sarper Karakadılar, “Türkiye'deki Elektronik Ticaret Uygulamalarına Müşteri Gözünden Bakış ve İyileştirme Önerileri”, İstanbul Gelișim Üniversitesi Sosyal Bilimler Dergisi,

6 (1), Nisan 2019, ss. 53-75

bulunmamaktadır. Bu nedenle internete güvenli giriş sertifikası için "TÜBİTAK" ile "Bilgi Teknolojileri ve İletişim Kurumu (BTK)" tarafından geliştirilen iki ayrı sistemin yakın gelecekte başarıyla uygulamaya geçebilmesi Türkiye'nin siber güvenliğinin sağlanabilmesi bakımından büyük önem taşımaktadır (Keser-Berber, 2017).

Siber güvenlikle ilgili bu iki gelişmenin kamuoyuna etkin bir şekilde duyurulması sayesinde Türk halkının internet ortamında ki başta bankacılık olmak üzere tüm eticaret işlemlerini daha gönül rahatlığıyla kullanmaya başlaması mümkün olacaktır. $\mathrm{Bu}$ sayede hem yeni kullanıcıların uygulamaya geçmesi hem de mevcut kullanıcıların çok daha yoğun bir şekilde e-ticaret işlemlerini kullanmaya başlamasıyla birlikte şirketlerin ișlem hacimleri ve dolayısıyla iș süreçlerinin verimliliği artacaktır.

\section{1. Çalışmanın Kısıtları ve Gelecek Araştırmalar İçin Öneriler}

Son olarak bu çalışma esnasında elde edilen deneyimlere göre gelecekte bu konuyu çalışacak araştırmacılar için bir takım önerilerin ortaya konulmasında da fayda vardır. Bu çalışma araştırma konusunu keşifsel bir yaklaşımla ele almakta ve sektörel bazda yapılmış pazar araştırmalarına benzer bir yapıda tasarlanmıștır. Ancak buna karşın araştırmanın tasarımında bazı kritik kısıtlar söz konusu olmuştur. Özellikle saha araştırmasının yürütülmesi için gerekli temel kaynaklar olan zaman ve araştırma bütçesinin yetersizliği nedeniyle çalışmada görece olarak yetersiz bir örneklem büyüklüğü ve bilimsel metodolojiden uzak bir șekilde basit-kolayda örnekleme yöntemi tercih edilerek uygulanmıştır. İleride yapılması muhtemel çalışmalarda, ana kütleyi temsil eden bir örneklem çerçevesi oluşturularak, söz konusu listeden tesadüfi olarak seçilen ve ülke geneline yayılan bir örneklem üzerinden yürütülecek bir araștırmanın bulgularının sektörel anlamda daha etkili çıkarımlar yapılmasına imkân vereceği kesindir.

İleride yapılacak olan araştırmalarda ana kütleyi temsil edecek ideal örneklem büyüklüğünün \%1 hata payına göre 16.666 kişiden oluşması gerektiği ve böylelikle daha gerçekçi sonuçların ortaya konulabileceği unutulmamalıdır (Kurtuluş, 2008, s.88-95). Ayrıca bu saha araştırmasının başlangıcında olması gereken 384 gözlemin üzerinde 400 civarı anket toplama hedefinin altında kalınmış olması da çalışmanın önemli bir kısıtı olarak dikkate alınmalıdır.

Yukarıda belirtilen tüm bu kısıtların yanında, bu araştırmanın öncelikli hedefinin Türkiye'deki e-ticaret müșterilerinin davranışsal tepkilerinin durum tespitini yapmaktır. $\mathrm{Bu}$ nedenle bu çalışmada bir yapısal araştırma modeli geliştirilip, bu modelle ilgili araştırma hipotezleri öne sürülmemiştir.

E-ticaret alışveriş uygulamalarına Türk müşterilerin verdikleri tepkileri gelecekte çalışmayı düşünen araştırmacılara hazırlayacakları araştırma tasarımında daha farklı yöntemler kullanarak konuyu ele almaları önerilebilir. Örneğin; Türkiye'deki farklı sektörlere yönelik (tekstil-moda; ev dekorasyon, mobilya; turizm rezervasyon gibi) e-ticaret uygulamaları için senaryolar geliştirilerek, daha kesin ayrımlar içeren bir yapıda daha bilimsel bir yaklaşımla araștırma soruları ele alınarak incelenmesi tavsiye edilebilir. 
Engin Yılmaz, İbrahim Sarper Karakadılar, “Türkiye'deki Elektronik Ticaret Uygulamalarına Müşteri Gözünden Bakış ve İyileştirme Önerileri”, İstanbul Gelişim Üniversitesi Sosyal Bilimler Dergisi, 6 (1), Nisan 2019, ss. 53-75

\section{KAYNAKÇA}

BULUT, Z. A. (2009). Elektronik pazarlamada stratejik konumlandırma süreci: Türkiye uygulamaları (Yayınlanmamıș Doktora Tezi). Dokuz Eylül Üniversitesi, Sosyal Bilimler Enstitüsü, İzmir.

ÇELİK, A. \& AKGEMİCİ, T. (1998). Girişimcilik Kültürü ve KOBİ'ler, Gazi Kitabevi, Ankara.

DÜNYA Ekonomi Gazetesi, (02.12.2017), Perakende satışların yüzde 10'u eticaret!. Erişim tarihi: 13.12.2018, https://www.dunya.com/ekonomi/perakendesatislarin-yuzde-10u-e-ticaret-haberi-392949

Elektronik Ticaret İşletmecileri Derneği (ETiD). 2018. Kişisel verilerin saklanması hakkında workshop. Erişim tarihi: 29.01.2018, http://www.etid.org.tr/haberler

ERBAȘLAR, G. \& DOKUR, Ș. (2012). Elektronik Ticaret: Genel bilgiler, hukuksal düzenlemeler, belge düzeni ve muhasebe işlemleri, Nobel Akademik Yayınları, Ankara.

Gümrük ve Ticaret Bakanlığı (GTB). 2018. Elektronik Ticaret Bilgi Sistemi. Erişim tarihi: 31.01.2018, https://www.gtb.gov.tr/duyurular/elektronik-ticaret-bilgi-sistemietbis-hizmete-acildi

HASILOĞLU, S. B. (1999). Enformasyon Toplumunda Elektronik Ticaret ve Stratejileri, Türkmen Kitapevi, İstanbul.

KALAYCI, C. (2008). Elektronik Ticaret ve KOBİlere Etkileri, Uluslararası Íktisadi ve İdari Incelemeler Dergisi, 1(1), s.139-150.

KARASAR, N. (2009). Bilimsel Araştırma Yöntemi, Nobel Akademik Yayınları, Ankara.

KESER BERBER, L. (2017). Türkiye'nin İnternet Güvenliği için Yerli Güvenlik Sistemi: e-Tuğra. Erişim tarihi: 6 Eylül 2017, https://www.ntv.com.tr/teknoloji/turkiyenin-internet-guvenligi-icin-yerli-guvenliksistemi-e-tugra,uciq0w9Sg06nFRBhWWv5gg

KORKMAZ, N. (2004). Sorularla e-ticaret, e-iş, işletme yönetiminde yeni eğilimler dizisi, İstanbul Ticaret Odasi Raporu.

KOTLER, P. (2000). Pazarlama Yönetimi, (çev. Nejat Muallimoğlu), Beta Yayınları, İstanbul.

KULA, V. \& TATOĞLU, E. (2002). KOBİ'lerde Elektronik Ticaret Kullanımını Etkileyen Faktörler, 7. Ulusal Pazarlama Kongresi Ankara.

KURTULUŞ, K. (2008). Pazarlama Araştırmaları, Filiz Kitabevi, İstanbul.

McLOUGHLIN, G. J. (01 Nisan 2002). Electronic commerce: an introduction. Erişim tarihi: 09.04.2017, https://usa.usembassy.de/etexts/bus/ecomintro.pdf

Mobilya Sanayicileri Derneği (MOSDER). (2015). Mobilya Tüketici Araştırması 2015. Erişim tarihi: 23.03.2017, http://www.mobilyago.com/tr/ipuclari/mobilyatuketici-arastirmasi-2015-mosder/

NTV Haber, (17.01.2017), Yerli arama motoru 'Geliyoo' test yayınına başladı. Erişim tarihi: 01.02.2018, https://www.ntv.com.tr/teknoloji/yerli-arama-motorugeliyoo-test-yayinina-basladi,A-OLCUWOKEerejH7rTNcBw 
Engin Yılmaz, İbrahim Sarper Karakadılar, "Türkiye'deki Elektronik Ticaret Uygulamalarına Müşteri Gözünden Bakış ve İyileştirme Önerileri", İstanbul Gelişim Üniversitesi Sosyal Bilimler Dergisi, 6 (1), Nisan 2019, ss. 53-75

Organization for Economic Cooperation and Development (OECD). (2000). Ecommerce: impacts and policy challenges: Economic Outlook 67. Erişim tarihi: 13.03.2017, https://www.oecd.org/eco/outlook/2087433.pdf

ÖZTÜRK, M. (2014). Elektronik pazarlama yöntemlerinin incelenmesi: Düzce tüketicisi üzerine bir araştırma (Yayınlanmamış Yüksek Lisans Tezi). Sakarya Üniversitesi, Fen Bilimleri Enstitüsü, Sakarya.

SARIHAN, T. D. (1995). Herkes İçin İnternet, Sistem Yayıncılık, İstanbul.

SARISAKAL, M. N. \& AYDIN, M. A. (2003). E-ticaretin yeni yüzü mobil ticaret. Journal of Aeronautics and Space Technologies, 1(2), s.83-90.

Türkiye Bilișim Sanayicileri Derneği (TÜBISAD). (2014). Türkiye E-Ticaret pazarının büyüklüğü 14 milyar TL, perakende içindeki payı ise yüzde 1,3. Erişim tarihi: 25.02.2017, https://webrazzi.com/2014/06/26/turkiye-eticaret-pazari-tubisadraporu/

Türkiye İstatistik Kurumu (TÜİK). (2016a). Türkiye'de internet kullanımı. Erişim tarihi: 5.05.2017, http://www.tuik.gov.tr/PreHaberBultenleri.do?id=21779

Türkiye İstatistik Kurumu (TÜİK). (2016b). Türkiye'de çalışan nüfus sayısı. Erişim tarihi: 5.05.2017, http://www.tuik.gov.tr/HbGetirHTML.do?id=27691

Türk Sanayicileri ve İş İnsanları Derneği (TÜSİAD). (2014). Dijital pazarın odak noktası E-ticaret. Erişim tarihi: 04.07.2017, https://webrazzi.com/2014/06/05/tusiadeticaret-raporu/

Türk Sanayicileri ve İș İnsanları Derneği (TÜSİAD). (2017). Dijitalleşen dünyada ekonominin itici gücü: E-ticaret. Erişim tarihi: 04.07.2017, http://www.eticaretraporu.org/wp-content/uploads/2017/04/TUSIAD_ETicaret Raporu 2017.pdf

WOLFINBARGER, M. \& GILLY, M. C. (2003). E-TailQ: Dimensionalizing, Measuring and Predicting Etail Quality, Journal of Retailing, 79 (3), s. 183-198.

\section{Summary}

The research motivation of this study to search for an answer that whether the e-commerce volume in Turkey why is not as intense as the developed and the other emerging countries' level. The essential of the research idea was supported by secondary sources provided by some of the industry association's reports of Turkish e-commerce business (such as TUBISAD; ETID; MOSDER; TUSIAD). These industry reports have presented some issues related to Turkish e-commerce market such as: although the Turkish e-commerce environment is quite suitable and Turkish e-commerce firms as active as for supplying the products/services in comparison with other emerging countries, still $e$ commerce market volume in Turkey is lower than the others. According to these industry reports, this result arises of the Turkish people refrain the potential risks of e-commerce implications in Turkey. In that context, the main aim of this study is to identify the Turkish e-commerce customers, who are the young and middle-aged and also well-educated people, shopping behavior experiences. We think this is very important because when these individuals increase their shopping intense on e-commerce applications, other parts of the 
Engin Yılmaz, İbrahim Sarper Karakadılar, “Türkiye'deki Elektronik Ticaret Uygulamalarına Müşteri Gözünden Bakış ve İyileştirme Önerileri”, İstanbul Gelișim Üniversitesi Sosyal Bilimler Dergisi, 6 (1), Nisan 2019, ss. 53-75

community would start using the e-commerce applications as well. Hence, firstly the Turkish e-commerce market firms should start to work for responding to the fears of this high-profile existing customers. Therefore this study was conducted for that purpose. Because of the main aim of this study, it only focuses on the B2C concept of the e-commerce. So the scope of the study is only the consumers market of e-commerce retailing. For this reason, the unit of analysis of this study was determined as the Turkish $e$ commerce customers who have already done shopping on Turkish e-retailing websites. And the sampling pattern was drawn from Istanbul, where the biggest is and the most cosmopolite city of Turkey.

The research content was established with two dimensions: the first one occurred as marketing research point of view, and the second one has benefited the academic research perspective as using the famous E-tail-Qual scale. The remarkable findings of the research could be summarized like these: The survey participants allocate less than a quartet of their average monthly incomes for their e-commerce expenditures. And also these participants mostly do not prefer to use more secure payments tools (such as sanalcard, BKM Express, etc.) while doing e-commerce transactions. Even though the survey participants are well-educated and aware of the internet-based transactions security precautions, they are still afraid of the hacking attacks on the server of e-commerce firms. Hereby they suppose that third party persons would get customers' personal information. Another significant problem for Turkish e-commerce customers, they cannot trust the all ecommerce suppliers in the market as some bad fraud experiences have been heard often.

Thus, based on these findings this study gives some improvement suggestions for the Turkish e-commerce industry. Firstly, to increase the perceived customer service on e-commerce transactions, Turkish e-commerce firms should generate a strategic alliance to bear the delivery job itself. Meanwhile, sector associations and public authority should take action to increase the trust perception of individuals. For instance; to provide that sector associations could notice the blacklist of e-commerce firms which are not satisfying to their customers. And public authority could establish a mechanism to assure the rights of customers with a simple and easy system. Moreover, public authority of e-commerce applications in Turkey should bear some more roles as a regulator in the market to increase the trust level of potential customers. Initially, the whole facilities in the business cycle such as warehouses of the suppliers, website sellers and the logistics service providers should be inspected by public authority frequently. Also, that office should certificate the goods/services which are selling on the websites in order to ensure the guarantee to the customers. 